\title{
Література:
}

1. Великий тлумачний словник сучасної української мови (з дод. i допов.). [уклад. і голов. ред. В. Т. Бусел]. Київ; Ірпінь : ВТФ «Перун», 2005. $1728 \mathrm{c}$.

2. Пещак М. М. Типи українських грамот XIV ст. та їх стилістичні особливості. Мовознавство. 1970. № 6. С. 58-65.

3. Українські грамоти XV ст. Підготовка тексту, вступна стаття і коментарі В. М. Русанівського. Київ : Наукова думка, 1965. 163 с.

4. Сухомлин I. Д. Питання становлення структури особових власних назв на основі народної антропонімічної системи української мови (За матеріалами пам'яток XIV-XVII ст. Українська лексика. Відп. ред. В. С. Ващенко. Дніпропетровськ : ДДУ, 1973. С. 3-19.

5. Худаш М. Л. Лексика українських ділових документів кінця XVI-початку XVII ст. (на матеріалі Львівського Ставропігіївського братства). Київ : Вид-во АН УРСР, 1961. 164 с.

DOI https://doi.org/10.30525/978-9934-26-039-1-3

\section{СЕМАНТИЧНА СТРУКТУРА ПРИКМЕТНИКІВ НА ПОЗНАЧЕННЯ ВЕЛИКОГО / МАЛОГО ЗАГАЛЬНОГО РОЗМІРУ (НА ПРИКЛАДІ ДРАМАТИЧНИХ ТВОРІВ ЛЕСІ УКРАЇНКИ)}

\author{
Клак О. С. \\ кандидат філологічних наук, \\ доцент кафедри іноземних мов та культури фахового мовлення \\ Львівського державного університету внутрішніх справ \\ м. Львів, Украӥна
}

Прикметники на позначення розміру (параметричні прикметники) об'єднують у єдину лексико-семантичну групу на основі інтегрального компонента «розмір фізичних об'єктів». Ця мікросистема неодноразово була об'єктом аналізу в науковій літературі на матеріалі різних мов (Н. Береговенко, Н. Векуа, А. Висоцький, Н. Дідух, А. Журинський, T. Линник, М. Петришин, Г. Шипіцина тощо), проте актуальним $є$ дослідження функціювання іï конституентів у художньому тексті, де вони часто виходять за межі своєї лексико-семантичної групи.

Лексична структура параметричних прикметників у драматичних творах Лесі Українки представлена одиницями, які формують окремі 
мікрогрупи зі значенням розміру й можуть перебувати як у бінарній опозиції один до одного, так і вживатись без антонімічних відповідників.

Мікрогрупа великого / малого загального розміру є найчисельнішою за кількістю слововживань. Визначення актуального смислу цих лексем залежить значною мірою від контекстуального оточення, у межах якого модифікується чи збагачується значення слова.

Конструкції «означення - означуване» достатньо для реалізації семем зі значення розміру конкретних предметів. При цьому в ролі означуваного виступає лексико-граматичний розряд конкретних іменників, зокрема: слова, які називають певні предмети (книга, ліра, окуляри, ятрець тощо); назви осіб, частин тіла (дідок, істота, очі); назви будівель, споруд та їх частин (світлиия): Евтім чіпляє ліру на великий канделябр, знявши з канделябра велику лампаду [4, с. 617].

Лексико-семантичний варіант «невеликий кількісно; нечисленний» [2] актуалізується в поєднанні $з$ іменником громадка, який позначає певну сукупність людей.

Прикметник малий набуває значення «невеликий віком; малолітній» [2], коли йдеться про дітей. У творах Лесі Українки зі значенням віку фіксують найчастотніше його вживання. Реалізації цього лексикосемантичного варіанта сприяє ширший контекст, у якому міститься вказівка на дії, ознаки чи властивості, характерні (чи, навпаки, не характерні) для дітей, наприклад: [Чарлі:] Коли дозволите, я подарую малій сестрі, вона просила ляльку [4, с. 286]; [Річард:] Хлопець дуже притомився, та й він малий для шарварків громадських [4, с. 223].

Більшість словопозначень великого й малого загального розміру в драматичних творах Лесі Українки втрачає понятійну співвідносність 3 відповідними категоріями, їх номінативний зв'язок 3 позначуваним ускладнюється додатковою інформацією про позитивну або негативну оцінку предмета чи явища, ступінь інтенсивності вияву дії або ознаки [3, c. 111]. Ці лексико-семантичні варіанти витворюються на грунті певних контекстуальних обставин у межах речення або словосполучення, вони зумовлені цим оточенням і осмислені ним. Творення переносних значень лексем великий та малий відбувається шляхом метафоричного перенесення ознак, властивостей природи, навколишнього матеріального світу на внутрішній світ людини, на сферу ії духовного життя. Таким чином, в основі метафоричного переносу лежить більша чи менша внутрішня схожість - подібність вражень, уявлень та їх оцінки.

Так, вторинні лексико-семантичні варіанти «який має чималу силу прояву, інтенсивність дії» [2] та «незначний за силою, ступенем свого вияву» [2] грунтується на метафоричному переносі «просторова 
характеристика предмета $\rightarrow$ почуття, характер людини». Контекстуальне оточення формують абстрактні іменники на позначення властивостей $\mathrm{i}$ ознак (сила), почуттів і психічного стану (ласка, надія, втіха), метафоричні сполуки (океан думок) тощо: [Річард:] ...Як мені вернутись в той край, де бачили мене колись у розивіті, де всі колись на мене великі надії покладали? [4, с. 319].

Значення прикметника великий «який має важливе значення» [2] актуалізується в поєднанні з іменниками заповіт, заповідь та назвами осіб у стійких словосполученнях великий пан, великий господь.

Контекст переносного значення «геніальний, загальновідомий, діяльність якого дуже високо оцінена» та його відтінку «який виділяється надзвичайною обдарованістю в чому-небудь; відомий» [2] становлять слова - найменування осіб за родом занять, діяльності. Для реалізації цього лексико-семантичного варіанта визначальну роль відіграє трикомпонентна конструкція, у якій міститься вказівка на певну сферу людської діяльності, наприклад: [Антоніо:] ...Коли дорівнює ученість ваша ввічливості - а в тім нема сумніву, - то ся нова земля пишатись може великим, дивним світочем науки [4, с. 311].

Отже, прикметникам на позначення великого / малого загального розміру в драматичних творах Лесі Українки властива широка семантика, окремі іх лексико-семантичні варіанти пов'язані між собою мотиваційними відношеннями. Актуалізації значення в художньому тексті сприяс двокомпонентна (означення - означуване) та трикомпонентна (означення - означуване - елементи контексту) структура. Особливістю вживання прикметників великий та малий є чисельна перевага в реалізації переносних значень та асиметричність значеннєвої структури слів-антонімів.

\section{Література:}

1. Дідух Н. Семантична структура параметричних прикметників. Вісник Львівського університету. Серія філологічна. Вип. 34. Ч. 1 Львів : Львівський нац. ун-т ім. І. Франка, 2004. С. 159-167.

2. Словник української мови : у 20 т. / НАН України, Укр. мов.інформ. фонд. T. 1-11. URL : https://services.ulif.org.ua/expl/Entry/ index? wordid $=7253 \&$ page $=267$

3. Сучасна українська літературна мова / за ред. А. П. Грищенка. Київ: Вища школа, 1997. 493 с.

4. Українка Леся. Твори: в 2 т. Т. 2 : Драматичні твори. Київ: Наукова думка, 1987. 728 с. 